\title{
THE INFLUENCE OF DEMOGRAPHIC AND ORGANIZATIONAL FACTORS ON KNOWLEDGE SHARING AMONG EMPLOYEES IN ORGANIZATIONS
}

\author{
Leposava Grubić-Nešić, Dejan Matić, Slavica Mitrović
}

Original scientific paper

This paper analyses various personal and organizational factors that affect knowledge sharing between employees in organizations. Personal factors involve general demographic characteristics i.e. gender, age and years of experience, and also technical, social or natural orientation of the profession of employees. Characteristics of organizations that were examined regarding knowledge sharing behaviour are the type of ownership and production or service activity of the organization. Results show that gender, level of education, organizational tenure and advance at work have significant impact on knowledge sharing. Regarding different types of organizations, the type of activities does not affect knowledge sharing, while the type of ownership does. Results have primarily practical implications for the design of managerial and organizational measures that would provide knowledge sharing and spreading in a more efficient manner and in accordance with the long-term strategic goals of the organization.

Keywords: demographic factors; employees; knowledge sharing; organizational factors; organizations

Utjecaj demografskih i organizacijskih faktora na dijeljenje znanja između zaposlenika u poduzećima

Izvorni znanstveni članak

U radu se analiziraju razne personalne i organizacijske značajke koje utječu na dijeljenje znanja između zaposlenika u poduzećima. Personalne značajke se odnose na opće demografske karakteristike kao što su npr. spol, starost i godine radnog staža, kao i na tehničku, društvenu ili prirodnu orijentaciju struke zaposlenika. Karakteristike poduzeća koje su ispitivane u odnosu na dijeljenje znanja između zaposlenika su tip vlasništva i proizvodna ili uslužna djelatnost poduzeća. Opće demografske i organizacijske značajke kao što su spol, stupanj obrazovanja, organizacijski staž i napredovanje na poslu imaju značajan utjecaj na dijeljenje znanja. Što se tiče različitih tipova organizacija, tip djelatnosti ne utječe na dijeljenje znanja, dok tip vlasništva ima utjecaj. Rezultati imaju prije svega praktične implikacije na koncipiranje upravljačkih i organizacijskih mjera kojima bi se omogućilo da se znanje dijeli i širi na efektivniji način i u skladu sa dugoročnim strategijskim ciljevima poduzeća.

Ključne riječi: demografski faktori; dijeljenje znanja; organizacijski faktori; poduzeće; zaposlenici

\section{Introduction}

Knowledge can be defined as a combination of experience, contextual information and expert concluding that provides a framework for the evaluation and application of new information and newly acquired experiences. It is today one of the key drivers of modern organizations and has the same importance as effectiveness and competitiveness [1]. Knowledge is one of the key parts of organizational processes, practices, norms and routines [2], and it arises in the minds of employees by interaction of their prior experience, intuition and attitude with imagination - the ability to visualize and create new ideas [3]. The most important characteristic of knowledge is its originality and uniqueness; when certain knowledge is created, it cannot be duplicated or replaced by some other knowledge, which makes it a key strategic resource of modern organizations [4].

Knowledge management can be defined as a process of conquest, storage, transfer and application of knowledge [5, 6, 7]. This concept involves people, technology and processes as correlated and overlapped parts [8]. The concept of knowledge management is focused, as many studies show, less on the technology and more on people $[9,10,11,12,13]$. Organizations invest a lot of effort and energy to maintain their competitive advantage, and to achieve through increased investment in its intangible assets - knowledge [14, 15, 16]. Knowledge management is a process by which organizations generate value from their intellectual assets based on knowledge [17].

Intellectual property of an organization can be classified into two categories: explicit and tacit knowledge. Explicit knowledge is contained in databases and public documents, while about $95 \%$ of all the information in organizations exists as tacit knowledge knowledge that is contained in the minds of employees $[18,19,20]$. While explicit knowledge is codified and transmitted most commonly by technology, tacit knowledge is more embedded in social relationships and is mainly transmitted by direct social interaction and observed behaviour. Tacit knowledge is, by its nature, difficult to articulate and, for the same reason, to share [21]. It includes cognitive skills and technological skills derived from experiences, such as the knowledge, subjective vision, intuition, and premonition of an experienced craftsman [22]. Apprenticeships and job shadowing are often used in attempts to share tacit knowledge, which are more time consuming approaches [23].

\section{Theoretical background}

Knowledge sharing can be conceptualized as an activity that provides transfer and exchange of knowledge in various forms between organizational members [21]. Knowledge sharing in the right way and the implementation of knowledge management in organizations enables employees to fully utilize all the benefits that this concept provides. Knowledge sharing is a process in which internal (tacit) knowledge of an individual can be converted into comprehensible and practically applicable knowledge of others. As a prerequisite knowledge sharing, an individual or a group must collaborate with other members of the organization 
in order to mutually share knowledge, resulting in common organizational benefit $[2,24]$. The process of generation of intellectual assets involves sharing of knowledge between employees, departments and even with other businesses if it is aimed at achieving organizational goals. This process is being realized through the possibility of generating new organizational knowledge arising from the process of knowledge sharing [25]. The objective is the creation of a business environment in which power lies in knowledge sharing between employees and not in a jealous and selfish keeping of that knowledge only for themselves [2].

Effective sharing and distribution of knowledge throughout the organization has a direct positive impact on the effectiveness and performance of organizations, and it can be easily seen that studying and understanding of employees' behaviour in terms of their willingness to share knowledge can have significant implications for organizations as well as organizational performances [26, 38]. An organization cannot effectively use knowledge without a proactive attitude of employees towards their knowledge sharing as well as acquiring knowledge of others [27]. Many employees believe knowledge sharing hinders their efforts to stand out in comparison to their colleagues [28]. As authors [23] emphasize, previous studies have shown that reluctance in knowledge sharing may include the maintaining power differentials, confidentiality and competition, and culture. Organizational approaches to knowledge sharing should bear in mind that different cultures have different attitudes towards knowledge sharing. Knowledge leaders or chief knowledge officers should, according to that, implement the adequate set of organizational knowledge sharing routines in their organizations. When knowledge sharing within the organization is insufficient or limited, so-called knowledge gaps occur which lead to undesirable or insufficiently successful business results [29].

Demographics is the study of population factors such as the proportion of the population who are of a given race, gender, location or occupation, and also such general factors as population density, size of population and location [30]. Demographics are the quantifiable of the statistics of a given population, and are used to identify the study of quantifiable sub-set within a given population [31]. Demographic characteristics are widely used variables in relation to organizational commitment and, as it is shown in literature, there is a significant role of demographic factors in determining organizational commitment. Demographic factors such as age, gender, marital status and education are included in many studies of the impact of demographic factors on attitudes toward knowledge sharing, intentions to share knowledge or knowledge sharing behaviour.

\section{Research methodology}

Effective knowledge management requires reviewing of the possibilities of knowledge sharing, as well as knowledge sharing factors that are essential for the development and success of organizations. The main research question from which we started our work is how certain personal factors such as general demographic characteristics (i.e. gender, educational level, age) contribute to knowledge sharing and how certain characteristics of organizations such as the type of ownership and types of activities (service or production type of organizations) influence employees' attitudes towards knowledge sharing.

The aim of our research was to be able to better and more clearly understand the factors that affect decrease or increase participation of employees in the process of knowledge sharing within organizations. As it was shown in the literature, organizational environment or organizational context, in addition to personal motivators, have a significant impact on employee behaviour aimed at knowledge sharing in organizations [33]. Our research was based on previous studies that have dealt with the transfer knowledge among employees in organizations [27], linking the intentions to share knowledge and action - participating in the process of knowledge sharing throughout the organization [32]. The research objectives are focused on identifying the factors that determine the methods and quality of knowledge sharing among employees in organizations, in order to implement managerial measures that promote knowledge sharing among employees as well as the creation of new individual and organizational knowledge.

Based on the research objectives, the following research hypotheses were defined:

- H1: There are differences in knowledge sharing of employees in relation to the following general demographic characteristics: gender, age, education level, years of experience and organizational tenure.

- H2: There are differences in knowledge sharing of employees related to their advance at work.

- H3: There are differences in knowledge sharing of employees related to different professions.

- H4: There are differences in attitude toward knowledge sharing of employees from service and manufacturing organizations.

- H5: There are differences in attitude toward knowledge sharing between employees from public and private organizations.

\section{Sample and procedure}

We used a quantitative survey and conducted surveying of employees from all hierarchical levels in organizations using a closed questionnaire directly - by distributing questionnaires to organizations, and electronically - via a specialized internet service for electronic surveys. Our survey included public and private organizations, as well as representative offices of foreign companies.

Research was conducted in 2013 in various Central European organizations as a part of a broader study investigating multiple correlations among organizational behaviour variables and knowledge sharing modelled through two theories: the theory of reasoned action (TRA) and the theory of planned behaviour (TPB). Other partial results and the overall results of this study will be represented and published in several phases during 2014 and 2015. A total of 1799 sets of questionnaires were distributed to 50 organizations with a return rate of 901 sets including the online survey, making a $50 \%$ return rate. 5 sets were eliminated, so the operational value was 
876 sets of questionnaires. Data represented in this paper was entirely analysed using IBM SPSS statistics software. The summarized sample description is shown in the Tab. 1 .

Table 1 Sample description

\begin{tabular}{|c|c|c|c|}
\hline & & Frequency & Percentage, $\%$ \\
\hline \multirow{2}{*}{ Gender } & Male & 298 & 34,1 \\
\hline & Female & 575 & 65,9 \\
\hline \multirow{4}{*}{ Education } & High school & 187 & 21,4 \\
\hline & College & 47 & 5,4 \\
\hline & University degree & 566 & 64,8 \\
\hline & Post graduate, $\mathrm{PhD}$ & 73 & 8,4 \\
\hline \multirow{3}{*}{$\begin{array}{l}\text { Type of } \\
\text { profession }\end{array}$} & Technical & 272 & 31,2 \\
\hline & Natural & 151 & 17,3 \\
\hline & Social & 450 & 51,5 \\
\hline \multirow{5}{*}{$\begin{array}{l}\text { Tenure in } \\
\text { organization }\end{array}$} & Less than 6 months & 38 & 4,4 \\
\hline & Between 6 and 12 months & 39 & 4,5 \\
\hline & $1 \div 2$ years & 84 & 9,6 \\
\hline & $3 \div 5$ years & 106 & 12,1 \\
\hline & More than 5 years & 606 & 69,4 \\
\hline \multirow{3}{*}{$\begin{array}{l}\text { Advance at } \\
\text { work }\end{array}$} & Promoted & 198 & 22,7 \\
\hline & Same rank & 644 & 73,8 \\
\hline & Demoted & 31 & 3,6 \\
\hline \multirow{5}{*}{$\begin{array}{l}\text { Position in } \\
\text { organization }\end{array}$} & Top management & 196 & 22,5 \\
\hline & Middle management & 343 & 39,3 \\
\hline & Lower level management & 66 & 7,6 \\
\hline & Supervisor & 16 & 1,8 \\
\hline & Worker & 252 & 28,9 \\
\hline \multirow{2}{*}{ Ownership } & Public & 754 & 86,4 \\
\hline & Private & 119 & 13,6 \\
\hline \multirow{3}{*}{$\begin{array}{l}\text { Type of } \\
\text { organization }\end{array}$} & Manufacturing & 62 & 7,1 \\
\hline & Service & 811 & 92,9 \\
\hline & Other & 0 & 0,0 \\
\hline
\end{tabular}

\section{Instruments}

Several questionnaires were included in this research. The first questionnaire is a general one, concerning basic information about the respondents, their job and organization. This questionnaire is not a standardized one - the authors generated it for the purpose of this study. The goal of this questionnaire was to collect data about the general demographic characteristics of the respondents, as well as about the nature of their job, the hierarchical position they hold in the organization, and also about the organization they work in. Some of the elements of this questionnaire are age, education, job type, position, tenure, type of organization, etc.

The organizational climate questionnaire was adapted from [34] and also from [35]. The empowering leadership questionnaire (ELQ) is based on standardized ELQ questionnaire [36] adapted by [35]. The extrinsic and intrinsic drivers (motivators) questionnaires were adapted from [34, 37]. The subjective norm questionnaire was adapted from [34]. The attitude toward knowledge sharing questionnaire was adapted from [34, 35], the intention to share knowledge was adapted from [34]. Finally, the knowledge sharing behaviour questionnaire is Reychav \& Weisberg's ETKS questionnaire [32] adapted according to [35].

\section{Results and discussion}

To investigate the statistical dependence between two variables, we used Spearman's rank correlation $\left(\rho_{\mathrm{S}}\right)$ as an appropriate nonparametric measure. The examined independent variables age, years of experience, organizational tenure, advance at work, position in organization and the level of education showed the following results: higher scores on affiliation, innovation, fairness, lead by example, participative decision making, coaching, informing, showing concern and motivation to comply are associated with a lower number of years of life, fewer years of experience and shorter organizational tenure. Higher score on the scale attitude toward knowledge sharing is associated with shorter organizational tenure.

Employees who have been promoted at work had higher scores on the following scales: affiliation, innovativeness, leadership by example, participative decision making, expected reciprocal relationship, sense of self-worth, normative beliefs on knowledge sharing, attitude toward knowledge sharing, intention to share tacit knowledge, intention to share knowledge, tacit knowledge sharing behaviour and knowledge sharing behaviour.

Respondents who have higher positions in their organizations had in this study higher scores on the following scales: intention to share explicit knowledge, intention to share tacit knowledge, intention to share knowledge, explicit knowledge sharing behaviour, tacit knowledge sharing behaviour and knowledge sharing behaviour. On the other hand, respondents with higher levels of education had lower scores on the following scales: affiliation, employee care, anticipated extrinsic rewards, anticipated reciprocal relationships, normative beliefs, motivation to comply and intention to share tacit knowledge.

Statistically significant differences were found in terms of gender characteristics. The $t$-test statistical method revealed significant gender differences in scores on the following scales in a way that women had higher scores on both the scale intention to share explicit knowledge and the scale explicit knowledge sharing behaviour.

- Intention to share explicit knowledge $(t=-2,627, p=0,009)$,

- Explicit knowledge sharing behaviour $(t=-2,116, p=0,035)$.

Using $t$-test we found out that respondents from private organizations had significantly higher scores on the following scales:

- Affiliation $(t=-4,851, p=0,000)$,

- Innovativeness $(t=-4,151, p=0,000)$,

- Fairness $(t=-2,269, p=0,023)$,

- $\quad$ Lead by example $(t=-2,968, p=0,003)$,

- Participative decision making $(t=-2,851, p=0,004)$,

- Coaching $(t=-3,635, \mathrm{p}=0,000)$,

- Anticipated reciprocal relationships $(t=-2,439, p=0,015)$,

- Normative beliefs on knowledge sharing $(t=-5,691, p=0,000)$,

- Motivation to comply $(t=-4,551, p=0,000)$,

- Attitude toward knowledge sharing $(t=-5,464, p=0,000)$,

- Intention to share tacit knowledge $(t=-3,351, p=0,001)$, 
- Intention to share knowledge

- $(t=-2,623, p=0,009)$,

- $\quad$ Tacit knowledge sharing behaviour $(t=-2,97, p=0,003)$,

- Knowledge sharing behaviour $(t=-1,989, p=0,047)$.

Furthermore, $t$-test revealed that respondents from service organizations had significantly higher scores on the following scales:

- Fairness $(t=-3,275, p=0,001)$,

- Lead by example $(t=-2,322, p=0,020)$,

- Participative decision making $(t=2,592, p=0,010)$,

- Coaching $(t=-2,425, p=0,016)$,

- Informing $(t=-2,94, p=0,003)$,

- Showing concern $(t=-3,061, p=0,002)$,

- Normative beliefs on knowledge sharing $(t=-1,967, p=0,049)$,

- Motivation to comply $(t=-2,492, p=0,013)$.

One-way analysis of variance (ANOVA) showed differences between respondents of different professions on the following scales:

- Affiliation $(F(2,870)=3,809, p=0,023)$,

- Attitude toward knowledge sharing

$$
(F(2,870)=4,761, p=0,009) \text {. }
$$

The following table shows the results of Tukey's HSD test on scales affiliation and attitude toward knowledge sharing for different fields of professions (Tab. 2).

\begin{tabular}{|c|c|c|c|c|c|}
\hline & $\begin{array}{l}\text { (I) Field of } \\
\text { profession }\end{array}$ & $\begin{array}{l}(J) \text { Field of } \\
\text { profession }\end{array}$ & $\begin{array}{c}\text { Mean } \\
\text { difference } \\
(I-J)\end{array}$ & $\begin{array}{l}\text { Std. } \\
\text { Error } \\
(S E)\end{array}$ & Sig. $(p)$ \\
\hline \multirow{3}{*}{ Affiliation } & Technical & Natural & 0,722 & 0,349 & 0,097 \\
\hline & & Social & $0,684 *$ & 0,264 & $0,027^{*}$ \\
\hline & Natural & Social & $-0,038$ & 0,324 & 0,992 \\
\hline \multirow{3}{*}{$\begin{array}{l}\text { Attitude } \\
\text { toward } \\
\text { knowledge } \\
\text { sharing }\end{array}$} & Technical & Natural & $-0,202$ & 0,392 & 0,864 \\
\hline & & Social & $-0,868^{*}$ & 0,297 & $0,010 * *$ \\
\hline & Natural & Social & $-0,666$ & 0,363 & 0,159 \\
\hline
\end{tabular}

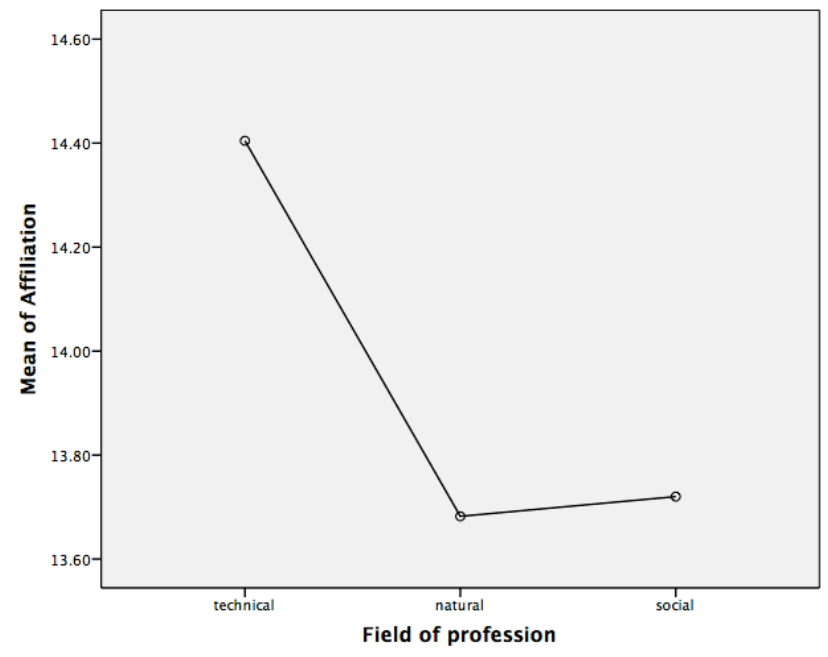

Figure 1 Tukey's HSD test for affiliation
Tukey's honest significance difference test (Tukey's HSD) determined difference between respondents of different professions on the scale affiliation: technical profession respondents had a higher score. The average values for respondents with different professions on the scale affiliation are presented in Fig. 1.

Tukey's honest significance difference test determined statistically significant difference between respondents of technical and social professions on the scale attitude toward knowledge sharing: respondents of technical profession had lower scores. The average values for respondents of different professions in scores on the scale attitude toward knowledge sharing are presented in Fig. 2.

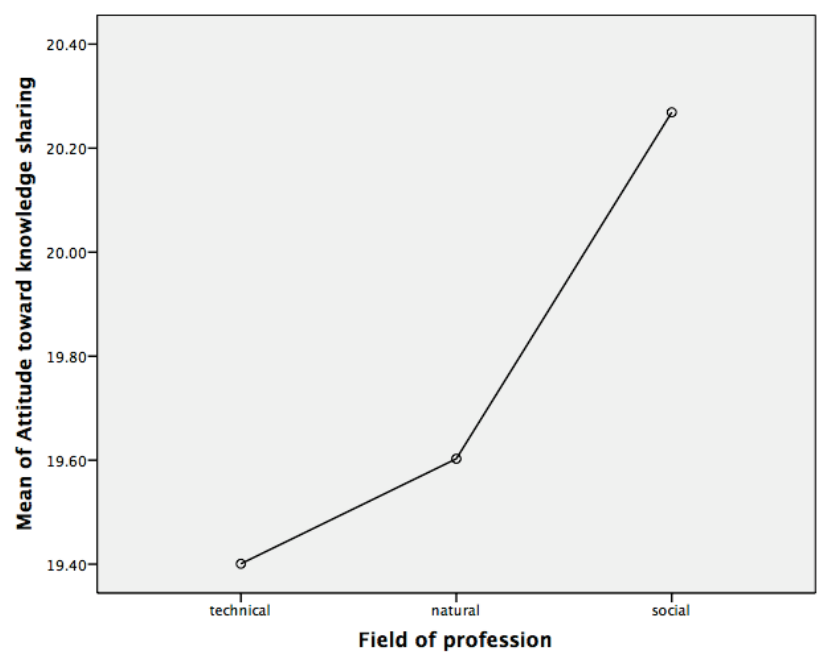

Figure 2 Tukey's HSD test for attitude toward knowledge sharing

These results show that variables age and years of work experience do not have direct effects on variables defining the process of knowledge sharing i.e. attitude toward knowledge sharing, intention to share knowledge and knowledge sharing behaviour, but they have a direct effect on organizational behaviour variables such as affiliation, fairness, showing concern, motivation to comply etc. The $t$-test revealed that women had higher scores on variables intention to share explicit knowledge and explicit knowledge sharing behaviour. Furthermore, respondents who hold higher positions in their organizations had higher scores on knowledge sharing intentions and knowledge sharing behaviour variables, specifically on tacit knowledge variables, but they did not have higher scores on normative beliefs on knowledge sharing and attitude toward knowledge sharing. Finally, respondents with higher level of education had lower scores on the following scales: normative beliefs on knowledge sharing and intention to share tacit knowledge.

From these findings we can conclude that our hypothesis $\mathrm{H} 1$ is only partially supported, since age and years of experience do not have significant effect on knowledge sharing variables, gender differences have significant impact on explicit knowledge sharing behaviour, level of education has significant impact on normative beliefs on knowledge sharing and intention to share tacit knowledge and, finally, organizational tenure has significant impact on attitude toward knowledge sharing. All other relations are non-significant regarding the variables that define the process of knowledge 


\section{sharing.}

Respondents who have advanced at work had higher scores on all of the knowledge sharing variables, and specifically on tacit knowledge sharing intentions and behaviour. From these findings we can conclude that hypothesis $\mathrm{H} 2$ is fully supported.

ANOVA test and Tukey's HSD test have determined that respondents from technical professions had higher scores on affiliation, while respondents from social professions had higher scores on attitude toward knowledge sharing. From these findings we can conclude that hypothesis $\mathrm{H} 3$ is mostly unsupported since there was no significant impact of differences between professions on knowledge sharing, except the fact that respondents from social professions had higher scores on attitude toward knowledge sharing, which is only an indirect effect on knowledge sharing behaviour.

As it was shown before in this paper, respondents from service organizations had significantly higher scores on normative beliefs on knowledge sharing, but not on other knowledge sharing variables, so these results imply that hypothesis H4 is unsupported.

Finally, $t$-test revealed that respondents from private organizations had significantly higher scores on all knowledge sharing variables (and specifically on tacit knowledge sharing variables) thus fully supporting hypothesis $\mathrm{H} 5$.

\section{Conclusion}

These results extend, further clarify and deepen the findings obtained in earlier studies and combine them into a single framework of organizational variables that affect the process of knowledge sharing between employees in organizations, and as well determine the intensity and significance of certain direct and indirect impacts between variables in the proposed research model.

The main question to which this paper was supposed to provide an answer is whether general demographic characteristics of employees and characteristics of their jobs and organizations have influence on knowledge sharing behaviour in Central European social and organizational context? In general, several main conclusions can be drawn from the results of the analysis:

- It was shown that knowledge sharing between employees in organizations depends on a number of personal and organizational factors.

- General demographic and organizational characteristics such as gender, level of education, organizational tenure and advance at work have significant impact on knowledge sharing.

- Age and years of experience and type of profession do not have significant direct impact on knowledge sharing.

- Regarding different types of organizations, the type of activities does not affect knowledge sharing, while the type of ownership does.

Limitations of this study are linked to the social and organizational context where the research was conducted so it is likely that these results cannot be universally and a priori accepted in different cultural contexts and clusters. Another limitation is that indirect effects on knowledge sharing variables were not examined in this paper; further research is needed to more deeply explore and explain these important organizational behaviour variables.

Results of this research can be considered as useful primarily for practical reasons, because according to them knowledge leaders and chief knowledge officers in organizations can conceptualize measures that would contribute to the improvement of knowledge sharing processes and knowledge sharing behaviour among employees thus improving organizational performance.

\section{References}

[1] Wiig, K. People-focused knowledge management: How effective decision making leads to corporate success. Elsevier Butterworth-Heinemann. Burlington, MA, 2004.

[2] Al-Alawi, A. I.; Al-Marzooqi, N. Y.; Mohammed, Y. F. Organizational culture and knowledge sharing: Critical success factors. // Journal of Knowledge Management. 11, 2(2007), pp. 22-42. DOI: 10.1108/13673270710738898

[3] Iske, P.; Boersma, W. Connected brains-question and answer systems for knowledge sharing: Concepts, implementation and return on investment. // Journal of Knowledge Management. 9, 1(2005), pp. 126-145. DOl: $10.1108 / 13673270510583018$

[4] Cabrera, A.; Cabrera, E. F. Knowledge sharing dilemmas. // Organization Studies. 23, 5(2002), pp. 687-710. DOl: 10.1177/0170840602235001

[5] Davenport, T. H.; Prusak, L. Working knowledge: How organizations manage what they know. Harvard Business School Press. Boston, MA, 1998.

[6] Davenport, T. H.; Prusak, L. Working Knowledge: How organizations manage what they know. $2^{\text {nd }}$ ed. Harvard Business School Press. Boston, MA, 2000.

[7] Davenport, T. H.; DeLong, D. W.; Beers, M. C. Successful knowledge management projects. // Sloan Management Review. 39, 2(1998), pp. 43-57.

[8] Award, E. M.; Ghaziri, H. M. Knowledge management. Pearson Education International / Prentice Hall, Englewood Cliffs, NJ, 2004.

[9] Jennex, M. A. Knowledge management in modern organizations. Idea Group Inc (IGI). Hershey, PA, 2007. DOI: 10.4018/978-1-59904-261-9

[10] Malhotra, Y. Knowledge management in inquiring organizations. // Proceedings of the $3^{\text {rd }}$ Americas Conference on Information Systems / Indianapolis, 1997, pp. 293-295.

[11] Nonaka, I.; Takeuchi, H. The knowledge creating company: How Japanese companies create the dynamics of innovation. Oxford University Press. New York, NY, 1995.

[12] Sunasse, N.; Sewry, D. An investigation of knowledge management implementation strategies. // Proceedings of SAICIT / Pretoria, 2003, pp. 24-36.

[13] Tiwana, A. The knowledge management toolkit. PrenticeHall. Englewood Cliffs, NJ, 2000.

[14] Collins, C. J.; Smith, K. G. Knowledge exchange and combination: The role of human resource practices in the performance of high-technology firms. // Academy of Management Journal. 49, 3(2006), pp. 544-560. DOl: 10.5465/AMJ.2006.21794671

[15] Huber, G. P. The necessary nature of future firms: Attributes of survivors in a changing world. Sage Publications. Thousand Oaks, CA, 2004.

[16] Smith, K. G.; Collins, C. J.; Clark, K. D. Existing knowledge, knowledge creation capability, and the rate of new product introduction in high-technology firms. // Academy of Management Journal. 48, 2(2005), pp. 346357. DOI: 10.5465/AMJ.2005.16928421 
[17] Call, D. Knowledge management - not rocket science. // Journal of Knowledge Management. 9, 2(2005), pp. 19-30. DOI: $10.1108 / 13673270510590191$

[18] Nonaka, I. A dynamic theory of organizational knowledge creation. // Organization Science. 5, 1(1994), pp. 134-139. DOI: $10.1287 /$ orsc.5.1.14

[19] Polanyi, M. Personal knowledge: Towards a post critical philosophy. University of Chicago Press. Chicago, IL, 1958.

[20] Polanyi, M. The tacit dimension. Routledge \& Kegan Paul. London, England, 1966.

[21] McKenzie, K. M. Leveraging organisational tacit knowledge: Delivering knowledge based consulting solutions through interpersonal knowledge exchange. // The International Journal of Knowledge, Culture and Change Management. 3, (2003), pp. 141-155.

[22] Hsien, L. C.; Pei, N. F.; Yung, P. C.; Sheng, C. T. A study on the correlations between knowledge sharing behavior and organizational citizenship behavior in catering industry: The viewpoint of Theory of Planned Behavior. // Anthropologist. 17, 3(2014), pp. 873-881.

[23] McAdam, R., Mofflett, S., \& Peng, Y. Knowledge sharing in Chinese service organizations: A multi case cultural perspective. // Journal of Knowledge Management. 16, 1(2012), pp. 129-147. DOI: 10.1108/13673271211198981

[24] Syed-Ikhsan, S.; Rowland, F. Knowledge management in public organizations: A study on the relationship between organizational elements and the performance of knowledge transfer. // Journal of Knowledge Management, 8, 2(2004), pp. 95-111. DOI: 10.1108/13673270410529145

[25] Argote, L.: McEvily, B.; Reagans, R. Managing knowledge in organizations: An integrative framework and review of emerging themes. // Management Science. 49, 4(2003), pp. 571-582. DOI: $10.1287 / \mathrm{mnsc}$.49.4.571.14424

[26] Alavi, M.; Leidner, D. E. Knowledge management systems: Issues, challenges and benefits. Communications of the AIS. 1, 7(1999), pp. 2-36.

[27] Ipe, M. Knowledge sharing in organizations: A conceptual framework. // Human Resource Development Review. 2, 4(2003), pp. 337-359. DOI: 10.1177/1534484303257985

[28] Huber, G. P. Transfer of knowledge in knowledge management systems: Unexplored issues and suggested studies. // European Journal of Information Systems. 10, 2(2001), pp. 72-79. DOI: 10.1057/palgrave.ejis.3000399

[29] Baird, L.; Henderson, J. C. The knowledge engine. BarrettKoehler, San Francisco, CA, 2001.

[30] Blythe, J. Essentials of marketing. 3rd ed. Pearson Education Limited, Harlow, Essex, England, 2005.

[31] Amangala, T. A. The effect of demographic characteristics on organizational commitment: A study of salespersons in the soft drink industry in Nigeria. // European Journal of Business and Management. 5,18(2013), pp. 109-118.

[32] Reychav, I.; Weisberg, J. Bridging intention and behavior of knowledge sharing. // Journal of Knowledge Management. 14, 2(2010), pp. 285-300. DOl: 10.1108/13673271011032418

[33] Yoo, Y.; Torrey, B. National culture and knowledge management in a global learning organization. // Choo, C. W.; Bontis, N. The strategic management of intellectual capital and organizational knowledge. Oxford University Press. Oxford, England, 2002. pp. 421-434.

[34] Bock, G.; Zmud, R. W.; Young-Gul, K.; Jae-Nam, L. Behavioral intention formation in knowledge sharing: Examining the roles of extrinsic motivators, socialpsychological forces, and organizational climate. // MIS Quarterly. 29, 1(2005), pp. 87-111.

[35] Xue, Y.; Bradley, J.; Liang, H. Team climate, empowering leadership, and knowledge sharing. // Journal of Knowledge Management. 15, 2(2011), pp. 299-312. DOl: $10.1108 / 13673271111119709$
[36] Arnold, J. A.; Arad, S.; Rhoades, J. A.; Drasgow, F. The empowering leadership questionnaire: The construction and validation of a new scale for measuring leader behaviors. // Journal of Organizational Behavior. 21, 3(2000), pp. 249269. DOI: 10.1002/(SICl)1099-1379(200005)21:3<249::AIDJOB10>3.0.CO;2-\#

[37] Hung, S.; Durcikova, A.; Lai, H.; Lin, W. The influence of intrinsic and extrinsic motivation on individuals' knowledge sharing behavior. // International Journal of HumanComputer Studies. 69, 6(2011), pp. 415-427. DOI: 10.1016/j.jijhcs.2011.02.004

[38] Ralević, P. V.; Dragojlović, A.; Dobrodolac, M.; Denić, N. M.; Nešić, Z. Increasing organizational performance by human resource management. // Tehnički vjesnik-Technical Gazette. 22, 2(2015), pp. 263-269. DOI: 10.17559/TV20130905124436

\section{Authors' addresses}

Leposava Grubić-Nešić, Associate Prof. Ph.D.

University of Novi Sad

Faculty of Technical Sciences

Trg Dositeja Obradovića 6, 21000 Novi Sad, Serbia

E-mail: nesle@uns.ac.rs

Dejan Matić, Research Associate Ph.D.

University of Novi Sad

Faculty of Technical Sciences

Trg Dositeja Obradovića 6, 21000 Novi Sad, Serbia

E-mail: dejan.matic@uns.ac.rs

Slavica Mitrović, Assistant Prof. Ph.D.

University of Novi Sad

Faculty of Technical Sciences

Trg Dositeja Obradovića 6, 21000 Novi Sad, Serbia

E-mail: mslavica@uns.ac.rs 